\title{
Environmental Factors Preceding A $\beta 40$ Monomer to Oligomers and the Detection of Oligomers in Alzheimer's Disease Patient Serum
}

\author{
Yoichi Matsunaga and Midori Suenaga \\ Department of Medical Pharmacology, Faculty of Pharmaceutical Sciences, Tokushima Bunri University, Yamashiro-cho, \\ Tokushima 770-8514, Japan \\ Correspondence should be addressed to Yoichi Matsunaga, yoichima@ph.bunri-u.ac.jp
}

Received 11 August 2011; Revised 20 October 2011; Accepted 27 October 2011

Academic Editor: Jianning Wei

Copyright (C 2012 Y. Matsunaga and M. Suenaga. This is an open access article distributed under the Creative Commons Attribution License, which permits unrestricted use, distribution, and reproduction in any medium, provided the original work is properly cited.

We present here environmental factors including $\mathrm{pH}$ shifts, temperature, and metal ions surrounding $\mathrm{A} \beta 40$ monomer to precede the oligomers. We also suggest a new idea to detect $A \beta 40$ oligomers with anti-A $\beta 40$ monoclonal antibody using enzyme-linked immunosorbent assay. This method involves the different sensitivity of the thermal shifts between $\mathrm{A} \beta 40$ monomer and the oligomers. The idea is useful for the diagnostics of Alzheimer's disease to detect A $\beta 40$ oligomers in the serum from the patients.

\section{Introduction}

Alzheimer's disease (AD) is the most common of senile dementia and characterized by memory loss, deterioration of cognitive and behavioral processes and social life, and these symptoms showed no relief through the life. The major pathological hallmark of $\mathrm{AD}$ is the accumulated $\mathrm{A} \beta$ plaques in the extracellular liquid [1] and neurofibrillary tangles in the intracellular accumulation of hyperphosphorylated and misfolded tau protein [2-4]. Among the brain lesions that are affected in $\mathrm{AD}$ and contain the highest number of senile plaques are the amygdala [5] and hippocampus [6]. The amygdala is involved in modulation of behavior, emotion, and memory due to its vast afferent and efferent projections. It has been reported that although lesions of amygdala alone do not appear to impair spatial learning, they potentiate hippocampus lesion-induced disruption of spatial learning [7]. The $\mathrm{A} \beta$ plaques are mainly composed of $\beta$ structured fibrils made up to $\beta$-amyloid protein $40 / 42$ amino acid residues long $(\mathrm{A} \beta 40 / 42)$, and they are processed from amyloid precursor protein (APP) in neurons and secreted into the interstitial fluid space (IFS) of the brain in the soluble form [8] and cerebrospinal fluid (CSF) that help to clear $A \beta$ from IFS to the bloodstream $[9,10]$.
Some of misfolding mechanisms of $\mathrm{A} \beta$ to induce aggregation appear in $A D$ brain. Because the aggregated $A \beta$ is observed as extracellular structure, the concentration of $\mathrm{A} \beta$ in the ISF [15] and the environmental factors surrounding the protein may affect the process. Detection of the most toxic $\mathrm{A} \beta$ species to synapse and neuron [16] present during $\mathrm{A} \beta$ aggregation is a critical aspect in $\mathrm{AD}$ diagnostics. The molten-globule state of the protein that is a misfolding intermediate, $A \beta$ oligomers before $A \beta$ plaque formation is responsible for neuronal damages [17].

One possible model of direct $\mathrm{A} \beta$ cytotoxicity involves the cytopathic effect of amyloid fibrils, which are rich in $\beta$-sheets and thereby interact with cell surface receptors and result in aberrant activation of signal transduction pathways. This model in consistent with the observation of hyperphosphorylated focal adhesion kinase [18] and microtubule-associated tau protein [19]. Persistent binding and activation of cell surface receptors by amyloid fibrils may induce neuronal apoptosis. An alternative possibility of $A \beta s$ cytotoxicity is the direct damages to the cell surface membrane to form pores and induce calcium influx by hydrolytic activity of $A \beta 40$ oligomers [20]. Recent study reports calcium ions stimulate the formation of $\mathrm{A} \beta 40$ oligomers that causally implicated in neuronal toxicity of $\mathrm{AD}$ [21]. 


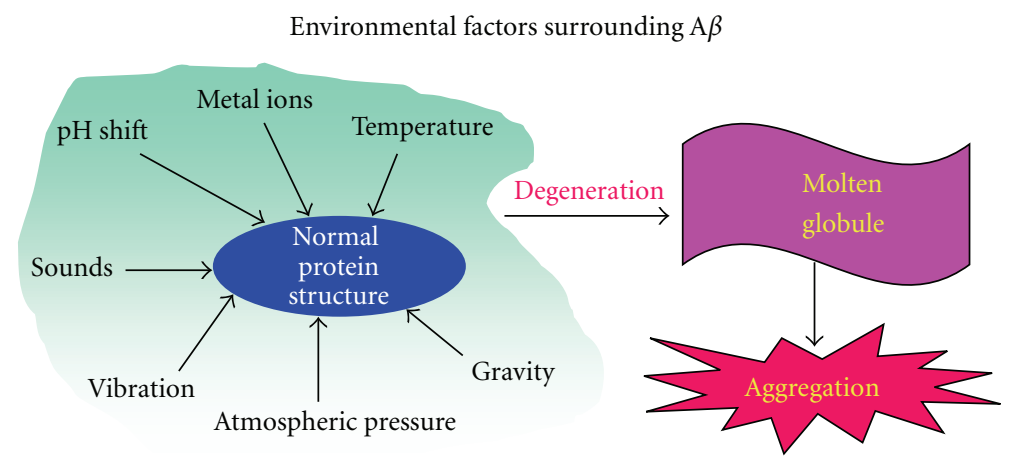

FIGURE 1: Environmental factors surrounding $A \beta 40$ to precede $A \beta 40$ oligomers. $A \beta$ s are exposed to the variety of environmental factors that affect the conformational changes. These factors involve $\mathrm{pH}$ shift, temperature, metal ions, sounds, gravity, atmospheric pressure, and vibration. These factors might be responsible to induce soluble $\mathrm{A} \beta$ monomer into oligomers which is a component of neurodegenerative process.

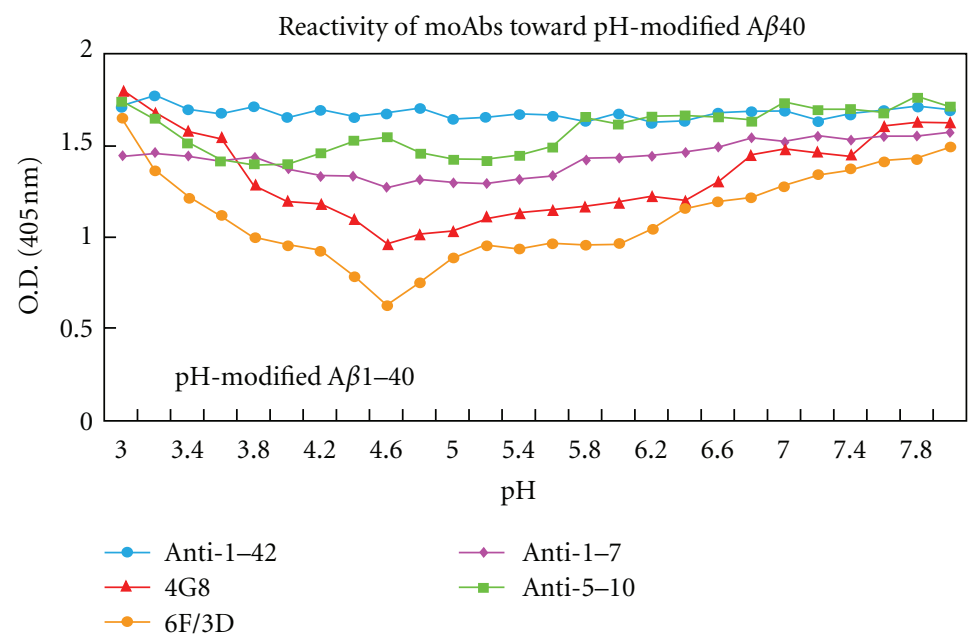

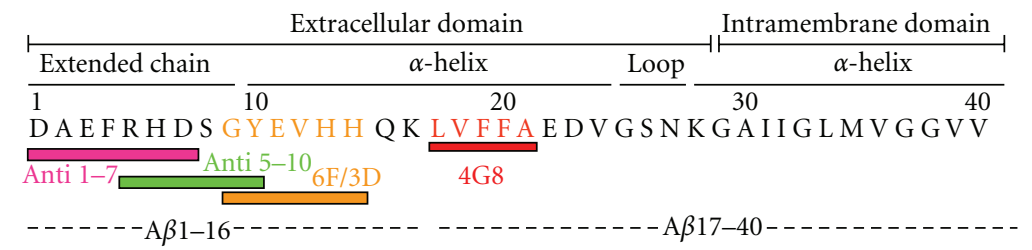

FIGURE 2: Reactivity patterns of antibodies differ after $\mathrm{pH}$-modification of the A $\beta 40$ peptide [11]. The $\mathrm{pH}$-modified A $\beta 40 \mathrm{peptides}(4 \mu \mathrm{g} / \mathrm{mL})$ at various $\mathrm{pH}$ values were tested for monoclonal antibody (e.g., anti-1-7 (fuchsia diamond), anti-5-10 (green square), 6F/3D (yellow circle), and 4G8 (red triangle)) and anti-1-42 (blue circle) which is a polyclonal antibody, binding at a concentration of $1 \mu \mathrm{g} / \mathrm{mL}$ on the standard ELISA system. Absorbance was measured at $405 \mathrm{~nm}$. Results are expressed as means \pm SEM $(n=6)$. The anti-1-7 and anti-5-10 antibodies showed very similar reactivity towards $\mathrm{A} \beta 40$ incubated at various $\mathrm{pH}$ values, the reactivity remaining constant over the entire $\mathrm{pH}$ range. In constant, the $6 \mathrm{~F} / 3 \mathrm{D}$ antibody showed decreasing reactivity as the $\mathrm{pH}$ was lowered from $\mathrm{pH} 8.0$ to 4.6 , followed by a dramatic increase as the $\mathrm{pH}$ was lowered from $\mathrm{pH} 4.6$ to 3.0. Interestingly, reactivity of the $4 \mathrm{G} 8$ antibody showed a profile similar to that shown by antibody $6 \mathrm{~F} / 3 \mathrm{D}$, with the lowest signal at $\mathrm{pH} 4.6$.

Many candidates of AD biomarker in blood, plasma, serum, and CSF are reported. The CSF levels of $A \beta 42$, tau and phosphorylated tau are potential biomarkers of $\mathrm{AD}$ [22], and plasma measures of $\mathrm{A} \beta$ are of limited diagnostic value but may provide important information as a measure of treatment response [23].

Many monoclonal antibodies (moAbs) to recognize A $\beta 40$ monomer are reported, and their epitopes are determined; however, there is no specific moAb for $A \beta 40$ oligomers. The conformational changes of A $\beta 40$ monomer to oligomers are induced in response to physiological environments surrounding $A \beta 40$, and some of $A \beta 40$ sequences are responsible to the changes. We used the moAb to react with the responsible sequence to the changes.

The A $\beta 40$ monomer is flexible and have high free energy before exposure to environmental changes, and the moAb shows high level of signals; however, after the exposure, its flexibility is constricted and free energy became low. In the 
Affinity of moAbs to $\mathrm{pH}$-modified $\operatorname{PrP}(29-231)$ and $\operatorname{Pr} \mathrm{P}(90-231)$

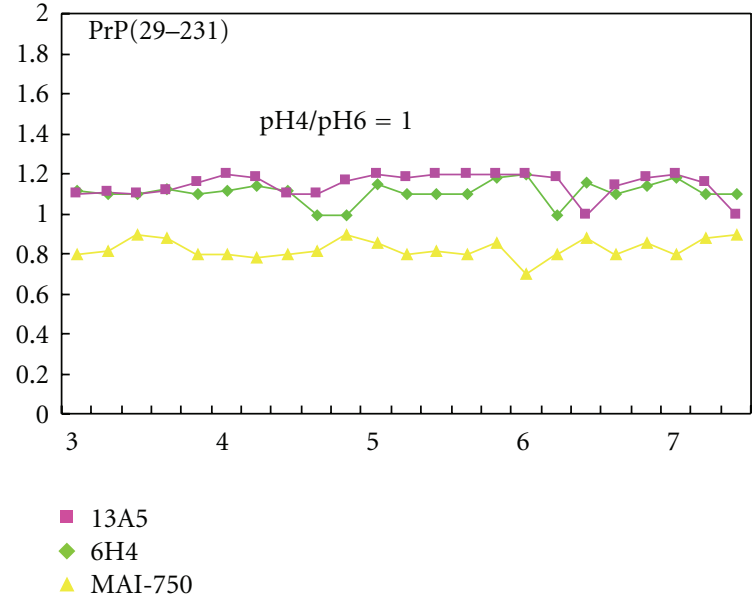

(a)

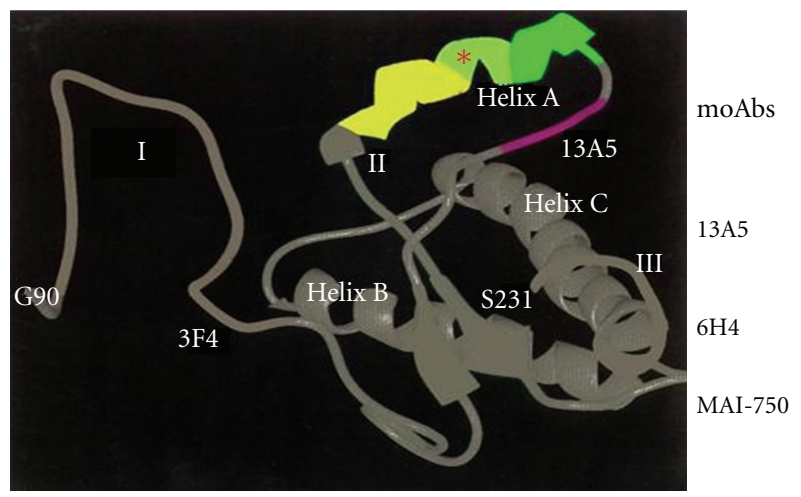

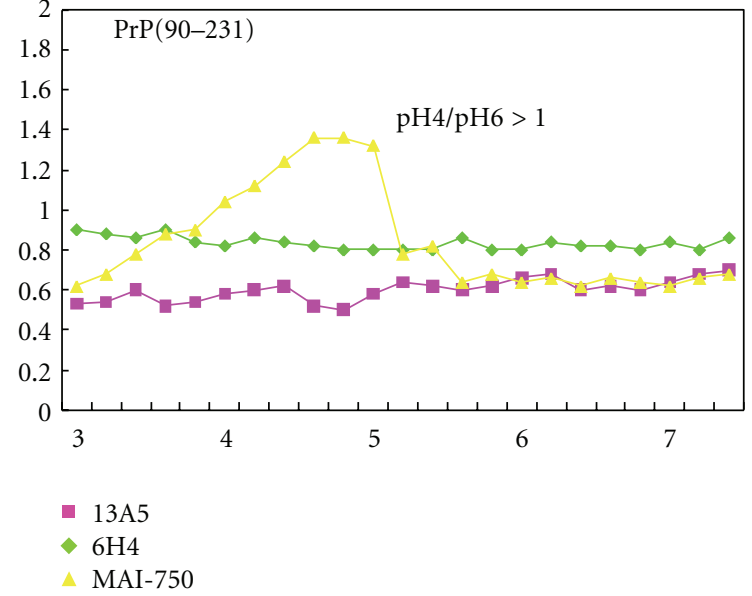

(b)

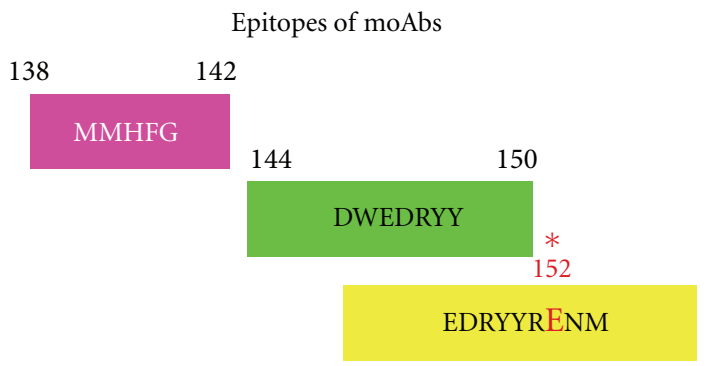

Figure 3: Affinity of moAbs to $\mathrm{pH}$-modified $\operatorname{PrP}(23-231)$ and $\operatorname{PrP}(90-231)$ [12]. The pH dependence of the affinity of rFab 13A5 (fuchsia square), mAb 6H4 (green diamond), and mAb MAI-750 (yellow triangle) toward (a) SHaPrP(29-231) and (b) SHaPrP(90-231) after incubation at various $\mathrm{pH}$ values within the range 3.0-7.2 was tested. Four acidic residues are clustered in the central region within the nine residues 144-152, and $\mathrm{rFab} 13 \mathrm{~A} 5, \mathrm{mAb} 6 \mathrm{H} 4$, and $\mathrm{mAb}$ MAI-750 could bind in this region. None of these antibodies showed any pH dependence of reactivity toward $\operatorname{PrP}(29-231)$, whereas MAI-750 showed a pH dependence around at pH 4 to 5 in its reactivity toward $\operatorname{PrP}(90-231)$. A further reduction in the reactivity of MAI-750 at very low pH suggests that the antibody is unable to bind to its epitope when the acidic groups are strongly protonated.

steps, some epitopes of the moAb are hidden inside the oligomers and the moAb could not bind to the epitopes, which resulted in the low level of signals. The remarkable fall down of reactivity of moAb towards $\mathrm{A} \beta 40$ monomer is useful to distinguish from $\mathrm{A} \beta 40$ oligomers, because the reactivity towards $A \beta 40$ oligomers show no changes before and after the exposure. We applied the idea to determine $A \beta 40$ forms in Alzheimer's disease patients serum.

\section{Environmental Factors Surrounding A $\beta 40$}

$\mathrm{A} \beta \mathrm{s}$ on the neuronal cell are exposed to various intracellular, and extracellular environmental factors in brain. A $\beta$ s are exposed to acidic $\mathrm{pH}$ in lysosome and extracellular factors surrounding $\mathrm{A} \beta \mathrm{s}$ involve temperature, metal ions, vibration, sounds, gravity, pressure, free radicals, lipid, concentration, and chemical chaperones [24]. These factors might be responsible to induce soluble $\mathrm{A} \beta$ monomers to molten-globule states of oligomers which are a component of neurodegenerative process and toxic to neuronal cells (Figure 1).

2.1. $p H$ Shifts. The native conformation of $\mathrm{A} \beta$ in $\mathrm{AD}$ and $\mathrm{PrP}$ in Scrapie is modulated by $\mathrm{pH}$ shift surrounding the protein, resulting in a "molten globule" state that is less ordered than native protein and is a folding intermediate to precede amyloid protein, however, still preserve the mean overall feature of the native protein [25].

In $\mathrm{A} \beta 40$, a critical $\mathrm{pH}$ to induce the conformational transition is at around $\mathrm{pH}$, which is a mimicking of a lysozomal $\mathrm{pH}[11]$. The responsible sequences to the $\mathrm{pH}$ shift was $A \beta$ 9-14:GYEVHH and 17-21:LVFFA, and the Glu at position 11 is most responsible to the acidic $\mathrm{pH}$ shift and induce soluble $\mathrm{A} \beta 40$ to insoluble form [26] (Figure 2).

Scrapie is a disease of protein misfolding of cellular prion protein $\left(\mathrm{PrP}^{\mathrm{c}}\right)$, in which the largely $\alpha$-helical and $\mathrm{PrP}^{\mathrm{c}}$ is converted to pathological isoform of scrapie $\operatorname{PrP}\left(\operatorname{Pr} \mathrm{P}^{s c}\right)$, that is rich in $\beta$-sheet $[27,28] . \operatorname{PrP}^{s c}$ is formed in caveolae 
and subsequently accumulated in endosomes and secondary lysosomes where the $\mathrm{pH}$ falls down to around $\mathrm{pH} 4-5$ [29]. A proteolytically truncated form of $\operatorname{PrP}^{\mathrm{cs}}$ corresponding to $\operatorname{PrP}(90-231)$ retains infectivity and form amyloid fibrils [30], and truncated $\operatorname{PrP}^{\mathrm{c}}(\operatorname{PrP} 90-231)$ with the same amino acid sequence can be converted to $\operatorname{PrP}^{\mathrm{sc}}$ in both cultured cells and transgenic mouse [31].

The $\mathrm{pH}$ dependence of $\operatorname{PrP}(90-231)$ was tested, and the moAbs which recognize amino acids sequence of 94105(GTHNQWNKPSKP), 107-112(TNMKHM), and 138142(MMHFG) of $\mathrm{PrP}^{\mathrm{c}}$ showed $\mathrm{pH}$-dependent reactivity. They showed high signals towards $\operatorname{PrP}(90-231)$ modified below $\mathrm{pH} 4.7$, and the signals fall down remarkably towards $\operatorname{PrP}(90-231)$ modified over $\mathrm{pH} 5.2$, suggesting that these regions of $\operatorname{PrP}(90-231)$ were sensitive to $\mathrm{pH}$ shifts; however, the signals from the same region of the full length of $\operatorname{PrP}(29$ 231) showed no sensitivity to the entire $\mathrm{pH}$ shifts. This $\mathrm{pH}$ dependence of $\operatorname{PrP}(90-231)$ suggests the titration of an acidic region that might inhibit the $\mathrm{N}$-terminal epitopes. A similar $\mathrm{pH}$ dependence for a monoclonal antibody reactive to the central region of 146-154(EDRYYRENM) identified an acidic region incorporating Glu152 as a significant participant (Figure 3) [12].

2.2. Temperature within Physiological Limits. Temperatureinduced transition of $A \beta 40$ plays an important role in the structural transformation from $\alpha$-helix and random coil to $\beta$-sheet form in aqueous solution by heating [32]. High temperature induces structural changes in $\mathrm{A} \beta$ (tangle and plaques) or changes in brain similar to those observed in $\mathrm{AD}$ [33]. The conformation of $\mathrm{A} \beta 40$ at $0-20^{\circ} \mathrm{C}$ was $\alpha$-helical, whereas conformational changes of $\mathrm{A} \beta 40$ towards $\beta$-sheet conformation were observed at between $35-45,60-65$, and $80-85^{\circ} \mathrm{C}[13]$.

The occurrence of changes within specific temperature ranges may indicate thermal specificity or adoption by $\mathrm{A} \beta 40$ of various conformations at wide range of heating, due to increasing intermolecular $\beta$-sheet structures [34]. The temperature within the physiological limits also induced the changes to $\mathrm{A} \beta 40$, the apparent changes were observed at 36$38^{\circ} \mathrm{C}$ in the amino acid residues $9-14$, and the changes in the amino acid residues $17-21$ were observed at $36-40^{\circ} \mathrm{C}$ [13], and both sequences have been reported to be involved in $\mathrm{pH}$ induced conformational transition of A $\beta 40$ [11] (Figure 4). The observation within physiological limits may occur in vivo with high fever over $38^{\circ} \mathrm{C}$ in response to inflammatory disease, and thermal stress may affect $\mathrm{A} \beta 40$ in our brain.

Temperature-dependent secondary structure of $A \beta 40$, $\mathrm{A} \beta 42$ and $\mathrm{A} \beta 28$ in the solid state was also studied by simultaneous Fourier transform infrared/differential scanning calorimetry (FT-IR/DSC) microspectroscopic system. Basically, $A \beta 28$ is composed from major $\beta$-sheet and minor $\alpha$-helix with little random coil, and $\mathrm{A} \beta 40$ consisted of major $\beta$-sheet, minor random coil, and little $\alpha$-helix, but $\mathrm{A} \beta 42$ mainly consisted of the predominant $\beta$-sheet structure. Thus, the intact $A \beta$ s show a different secondary structures, and thermal treatment induces a similar $\beta$-sheet structure for $\mathrm{A} \beta 40$ at $45^{\circ} \mathrm{C}$ and for $\mathrm{A} \beta 28$ at $40^{\circ} \mathrm{C}$; however, there

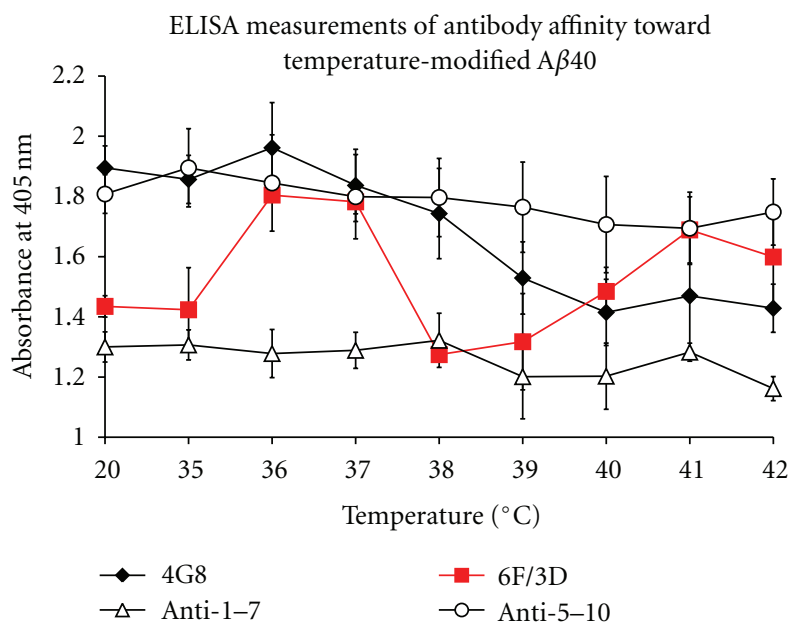

FIgURe 4: Affinity of moAbs to thermal-modified A $\beta 40$ [13]. Enzyme-linked immunosorbent assay (ELISA) measurements of antibody affinity towards temperature-modified $A \beta 40$ were performed. The reactivity of four antibodies as mentioned in Figure 2 ( $4 \mathrm{G} 8,6 \mathrm{~F} / 3 \mathrm{D}$, anti-1-7, anti-5-10) to samples of $\mathrm{A} \beta 40$ that had been exposed to temperatures over the range $36-42^{\circ} \mathrm{C}$ at $1^{\circ} \mathrm{C}$ interval and at $20^{\circ} \mathrm{C}$ as a control, was monitored by ELISA. Statistical comparisons were performed with unpaired $t$-tests. The values are means \pm SEM. Statistically significant differences versus $6 \mathrm{~F} / 3 \mathrm{D}$ were determined at each temperature $(n=6)$. For both anti5-10 and 1-7 antibodies, the reactivity was constant through the whole temperature range from $35^{\circ} \mathrm{C}$ to $42^{\circ} \mathrm{C}$, and no temperaturedependent difference was detected. The monoclonal antibody $6 \mathrm{~F} / 3 \mathrm{D}$ showed temperature-dependent reactivity, and the reactivity was bimodal, when the modified temperature was increased from 36 to $38^{\circ} \mathrm{C}$ and from 38 to $41^{\circ} \mathrm{C}$. On the other hand, 4G8 showed temperature-dependent reactivity, when the temperature increased from 36 to $40^{\circ} \mathrm{C}$. Thus, the $9-14$ and $17-21$ amino acid residues within $\mathrm{A} \beta 40$ peptide were sensitive to temperature changes.

was no transitional temperature for $\mathrm{A} \beta 42$ [35]. Actually, temperature at $45^{\circ} \mathrm{C}$ induced changes for $\mathrm{A} \beta 40$ by reducing the compositions from 37 to $20-24 \%$ for $\alpha$-helical and random coil structures but increasing the components from 27 to $45 \%$ for intermolecular $\beta$-sheet structures [34]. The thermal-induced denaturation is an important factor in the structural transformation from $\alpha$-helix/random coil to $\beta$ sheet in $\mathrm{A} \beta \mathrm{s}$.

2.3. Metal Ions. The metal ions such as $\mathrm{Zn}^{2+}, \mathrm{Cu}^{2+}$ were implicated in $\mathrm{AD}$ progression [36-38], and their interaction with $A \beta$ in stimulating $A \beta$ aggregation has been studied in vitro. The binding of metal ions induces $\mathrm{A} \beta$ conformation, initially rich in random coil structure to a $\beta$-sheet structure, favorable the partially folding intermediates. Under acidic $\mathrm{pH}, \mathrm{Cu}^{2+}$, and $\mathrm{Fe}^{3+}$ induce drastic aggregation; however, under neutral or alkaline $\mathrm{pH}$, they showed limited propensity to $A \beta$ aggregation [39-41]. Oligomerization of the $A \beta$ peptides can be rapidly induced in the presence of $\mathrm{Zn}^{2+}$ ions under physiological conditions [42-44], and, under both at alkaline and acidic $\mathrm{pH}$, it could induce $\mathrm{A} \beta$ aggregation and form protease resistant aggregates [45]. It was suggested that 


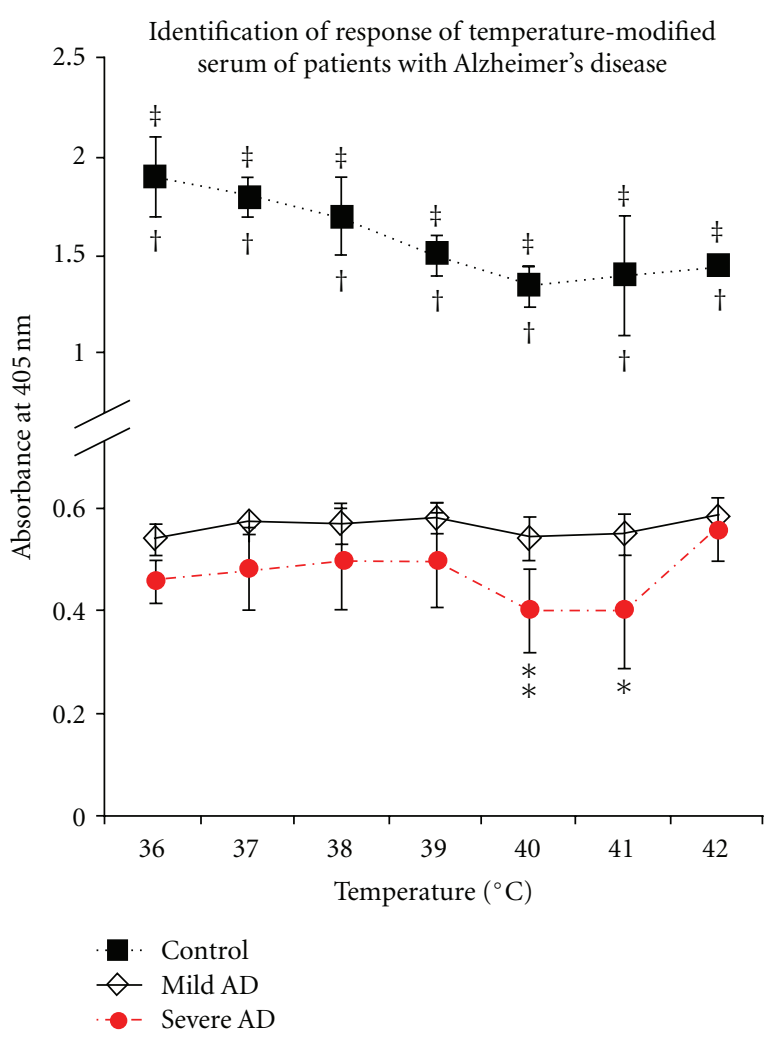

(a)

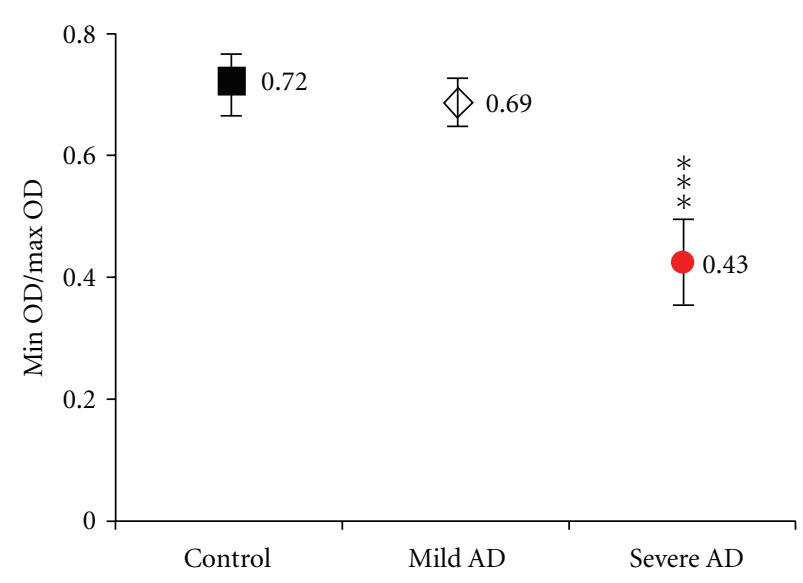

(b)

FIGURE 5: Identification of response of temperature-modified serum of patients with Alzheimer's disease [14]. According to the criteria of National Institute of Neurological and Communicative Disorders and Stroke/Alzheimer's Disease and Related Disorders, AD patients were enrolled, and the patients were classified into two groups of mild AD and severe AD with age match. MMSE score 1-9 was as severe AD and the score of 10-22 was as mild AD. Sera from two AD groups were tested for their reactivity against 4G8 with ELISA. (a) The absorbance in the severe $\mathrm{AD}$ was lower than that of the mild $\mathrm{AD}$ though the temperatures and the signals from mild $\mathrm{AD}$ were almost constant; however, the significant lower signal was observed in severe $\mathrm{AD}$ at $40^{\circ} \mathrm{C}(P<0.02)$ and $41^{\circ} \mathrm{C}(P<0.05)$. The signals from $\mathrm{A} \beta 40$ peptide as a control showed decrease as the temperature increase in a temperature-dependent manner. (b) The minimum/maximum optical density ratio of each patient's serum was calculated and obtained the average of ratios for severe and mild $\mathrm{AD}$. The ratio value for patients with severe $\mathrm{AD}$ $(0.43 \pm 0.05)$ was significantly $(P<0.001)$ lower than that for patients with mild $\mathrm{AD}(0.69 \pm 0.01)$. The average min/max optical density value for the synthetic $\mathrm{A} \beta 1-40$ peptide, used as a control, was $0.72 \pm 0.02$.

$\mathrm{A} \beta$ possesses preferential $\mathrm{Zn}^{2+}$-binding sites in its $\mathrm{N}$-terminal 1-16 and the metal ion interacts with His-6, -13, and 14 both at acidic and alkaline $\mathrm{pH}$ [46-48]. Recent reports suggests that soluble $A \beta$ oligomers rather than matured $A \beta$ fibrills exhibit the major neurotoxicity and these histidine residues may be a target to decrease the cytotoxicity [49] and suggested that a $\mathrm{Pt}$ compounds and $\mathrm{Ru}^{2+}$ complex may react with $\mathrm{A} \beta 28$ [50].

Recent report suggest the mechanisms and structures of amyloid formation by $\mathrm{Zn}^{2+}$ binding. Though $\mathrm{Zn}^{2+}$ does not affect the $\beta$-sheet association around the $\mathrm{C}$-terminal hydrophobic region, it shifts the relative aggregation major species. As a result, $\mathrm{Zn}^{2+}$ coordination promotes $\mathrm{A} \beta 42$ aggregation leading to less uniform structures and increasing $\mathrm{Zn}^{2+}$ concentration slows down the aggregation rate [51].

Though there are many reports to demonstrate the neurotoxic effects and their interference with a variety of cellular and metabolic process, the pathogenesis of $\mathrm{Al}^{3+}$ in $\mathrm{AD}$ is still under debate $[52,53]$. A comparative study under alkaline $\mathrm{pH}$ showed that $\mathrm{Zn}^{2+}$ and $\mathrm{Cu}^{2+}$ ions were much less efficient than $\mathrm{Al}^{3+}$ ion in stimulating the spontaneous fibril formation of $\mathrm{A} \beta \mathrm{s}$. The putative $\mathrm{Al}^{3+}$-chelating amino acid residues are present both in the hydrophilic segment $(\mathrm{A} \beta 1-$ $16)$ and in the hydrophobic core $(A \beta 20-35)$, suggesting that the $\mathrm{Al}^{3+}$-binding is less restricted than that for $\mathrm{Zn}^{2+}$ and $\mathrm{Cu}^{2+}$, which is confined to the $\mathrm{N}$-terminal sequence [54].

\section{Application of Temperature-Induced A 340 Conformational Changes for AD Diagnostics [14]}

The earlier intervention is required in $\mathrm{AD}$ treatments, and the determination of clinical phase of $\mathrm{AD}$ in early stage is necessary. Up to date, there are no reports about useful markers of AD staging.

We exposed $A \beta 40$ peptide to the thermal shifts and observed the reactivity pattern to moAbs with an enzymelinked immunosorbent assay (ELISA) before and after the 
exposures. The signals from $\mathrm{A} \beta 40$ before thermal exposure fall down after the exposure, in which $\mathrm{A} \beta 40$ oligomerization is induced by thermal shifts.

The clinical phase of $\mathrm{AD}$ was determined with MMSE, and mild $\mathrm{AD}$ presents MMSE over 24 and severe $\mathrm{AD}$ presents MMSE below 9. We used the sera from patients diagnosed with mild $\mathrm{AD}$ and severe $\mathrm{AD}$ to detect the different reactivity pattern to specific antibodies targeting $A \beta 17-$ $21(4 \mathrm{G} 8 \mathrm{moAb})$. The reactivity patterns of sera to $4 \mathrm{G} 8$ at $36-42^{\circ} \mathrm{C}$ was determined by ELISA. The A $\beta 40$ peptide as a control showed the reactivity pattern in a temperaturedependent manner, and the reactivity of sera from patients with severe $\mathrm{AD}$ was less than that of sera from patients with mild $\mathrm{AD}$ though the temperatures $36-41^{\circ} \mathrm{C}$ and the remarkable fall down at $41-42^{\circ} \mathrm{C}$ were shown in severe $\mathrm{AD}$, however, with no difference at $42^{\circ} \mathrm{C}$ (Figure $5(\mathrm{a})$ ). The severity of $\mathrm{AD}$ is associated with greater $\mathrm{A} \beta 40$ aggregation. We propose that the ratio of differences of signals with ELISA between $38^{\circ} \mathrm{C}$ and $40^{\circ} \mathrm{C}$ is useful to determine the severity of $\mathrm{AD}$ (Figure 5(b)). The present results may be of value in staging and following up of patients with $\mathrm{AD}$.

\section{Conclusion}

Acidic environment at around $\mathrm{pH} 5$, a temperature between $38-39^{\circ} \mathrm{C}$ within physiological limits, and $\mathrm{Cu}^{2+}$ and $\mathrm{Zn}^{2+}$ ion at neutral $\mathrm{pH}$ could precede $\mathrm{A} \beta 40$ from monomer to oligomers. The sequence of QKLVFFA is responsible of the changes, and it is crucial of $A \beta$ oligomerization, and the sequence may be useful as a biomarker of $A \beta 40$ oligomers in $\mathrm{AD}$ serum. The differences of $\mathrm{A} \beta 40$ conformation in $\mathrm{AD}$ patients serum were demonstrated as the different sensitivity of $A \beta 40$ in response to the thermal shift, and it was detected with the moAb which recognizes QKLVFFA, corresponding to amino acids $15-21$ of A $\beta 40 / 42$ by ELISA. We suggest here a new diagnostic approach for AD staging by monitoring the reactivity mode of the moAb to $A \beta 40$ before and after exposure to the thermal shift.

\section{References}

[1] R. Katzman and T. Saitoh, "Advances in Alzheimer's disease," FASEB Journal, vol. 5, no. 3, pp. 278-286, 1991.

[2] T. L. Spires-Jones, K. J. Kopeikina, R. M. Koffie, A. de Calignon, and B. T. Hyman, "Are tangles as toxic as they look?" Journal of Molecular Neuroscience, vol. 45, no. 3, pp. 438-444, 2011.

[3] J. Götz, A. Schild, F. Hoerndli, and L. Pennanen, "Amyloidinduced neurofibrillary tangle formation in Alzheimer's disease: insight from transgenic mouse and tissue-culture models," International Journal of Developmental Neuroscience, vol. 22, no. 7, pp. 453-465, 2004.

[4] J. Hardy and D. J. Selkoe, "The amyloid hypothesis of Alzheimer's disease: progress and problems on the road to therapeutics," Science, vol. 297, no. 5580, pp. 353-356, 2002.

[5] P. V. Arriagada, J. H. Growdon, E. T. Hedley-Whyte, and B. T. Hyman, "Neurofibrillary tangles but not senile plaques parallel duration and severity of Alzheimer's disease," Neurology, vol. 42, no. 3 I, pp. 631-639, 1992.
[6] Y. Fukutani, K. Kobayashi, I. Nakamura, K. Watanabe, K. Isaki, and N. J. Cairns, "Neurons, intracellular and extracellular neurofibrillary tangles in subdivisions of the hippocampal cortex in normal ageing and Alzheimer's disease," Neuroscience Letters, vol. 200, no. 1, pp. 57-60, 1995.

[7] J. P. Aggleton, H. S. Blindt, and J. N. Rawlins, "Effects of amygdaloid and amygdaloid-hippocampal lesions on object recognition and spatial working memory in rats," Behavioral Neuroscience, vol. 103, no. 5, pp. 962-974, 1989.

[8] J. R. Cirrito, P. C. May, M. A. O’Dell et al., "In vivo assessment of brain interstitial fluid with microdialysis reveals plaqueassociated changes in amyloid- $\beta$ metabolism and half-life," Journal of Neuroscience, vol. 23, no. 26, pp. 8844-8853, 2003.

[9] G. D. Silverberg, M. Mayo, T. Saul, E. Rubenstein, and D. McGuire, "Alzheimer's disease, normal-pressure hydrocephalus, and senescent changes in CSF circulatory physiology: a hypothesis," Lancet Neurology, vol. 2, no. 8, pp. 506-511, 2003.

[10] M. Shibata, S. Yamada, S. R. Kumar et al., "Clearance of Alzheimer's amyloid- $\beta 1-40$ peptide from brain by LDL receptor-related protein-1 at the blood-brain barrier," Journal of Clinical Investigation, vol. 106, no. 12, pp. 1489-1499, 2000.

[11] Y. Matsunaga, N. Saito, A. Fujii et al., "A pH-dependent conformational transition of $\mathrm{A} \beta$ peptide and physicochemical properties of the conformers in the glial cell," Biochemical Journal, vol. 361, no. 3, pp. 547-556, 2002.

[12] Y. Matsunaga, D. Peretz, A. Williamson et al., "Cryptic epitopes in N-terminally truncated prion protein are exposed in the full-length molecule: dependence of conformation on pH," Proteins, vol. 44, no. 2, pp. 110-118, 2001.

[13] F. F. Hatip, M. Suenaga, T. Yamada, and Y. Matsunaga, "Reversal of temperature-induced conformational changes in the amyloid-beta peptide, $\mathrm{A} \beta 40$, by the $\beta$-sheet breaker peptides 16-23 and 17-24," British Journal of Pharmacology, vol. 158, no. 4, pp. 1165-1172, 2009.

[14] F. F. Bolukbasi Hatip, Y. Matsunaga, and T. Yamada, "Specific reactivity of mild/severe Alzheimer's disease patient's sera to antibody against A $\beta 1-40$ epitope 17-21," Acta Neurologica Scandinavica, vol. 117, no. 6, pp. 404-408, 2008.

[15] A. W. Bero, P. Yan, J. H. Roh et al., "Neuronal activity regulates the regional vulnerability to amyloid- $\beta 2$ deposition," Nature Neuroscience, vol. 14, no. 6, pp. 750-756, 2011.

[16] J. A. Hardy and G. A. Higgins, "Alzheimer's disease: the amyloid cascade hypothesis," Science, vol. 256, no. 5054, pp. 184-185, 1992.

[17] C. Haass and D. J. Selkoe, "Soluble protein oligomers in neurodegeneration: lessons from the Alzheimer's amyloid $\beta$ peptide," Nature Reviews Molecular Cell Biology, vol. 8, no. 2, pp. 101-112, 2007.

[18] C. Zhang, M. P. Lambert, C. Bunch et al., "Focal adhesion kinase expressed by nerve cell lines shows increased tyrosine phosphorylation in response to Alzheimer's A $\beta$ peptide," Journal of Biological Chemistry, vol. 269, no. 41, pp. 2524725250, 1994.

[19] J. Busciglio, A. Lorenzo, J. Yeh, and B. A. Yankner, “ $\beta$-Amyloid fibrils induce tau phosphorylation and loss of microtubule binding," Neuron, vol. 14, no. 4, pp. 879-888, 1995.

[20] Y. Matsunaga, A. Fujii, A. Awasthi, J. Yokotani, T. Takakura, and T. Yamada, "Eight-residue A $\beta$ peptides inhibit the aggregation and enzymatic activity of A $\beta 42$," Regulatory Peptides, vol. 120, no. 1-3, pp. 227-236, 2004.

[21] A. Itkin, V. Dupres, Y. F. Dufrêne, B. Bechinger, J.-M. Ruysschaert, and V. Raussens, "Calcium ions promote formation of amyloid $\beta$-peptide (1-40) oligomers causally implicated in 
neuronal toxicity of Alzheimer's disease," PLoS ONE, vol. 6, no. 3, article e18250, 2011.

[22] B. J. Snider, A. M. Fagan, C. Roe et al., "Cerebrospinal fluid biomarkers and rate of cognitive decline in very mild dementia of the Alzheimer type," Archives of Neurology, vol. 66, no. 5, pp. 638-645, 2009.

[23] J. L. Cummings, "Biomarkers in Alzheimer's disease drug development," Alzheimer's and Dementia, vol. 7, no. 3, pp. e13-e44, 2011.

[24] J. McLaurin, D. Yang, C. M. Yip, and P. E. Fraser, "Review: modulating factors in amyloid- $\beta$ fibril formation," Journal of Structural Biology, vol. 130, no. 2-3, pp. 259-270, 2000.

[25] D. R. Booth, M. Sunde, V. Bellotti et al., "Instability, unfolding and aggregation of human lysozyme variants underlying amyloid fibrillogenesis," Nature, vol. 385, no. 6619, pp. 787793, 1997.

[26] Y. Matsunaga, E. Ierovnik, T. Yamada, and V. Turk, "Conformational changes preceding amyloid-fibril formation of amyloid-beta and stefin B; parallels in $\mathrm{pH}$ dependence," Current Medicinal Chemistry, vol. 9, no. 19, pp. 1717-1724, 2002.

[27] E. Turk, D. B. Teplow, L. E. Hood, and S. B. Prusiner, "Purification and properties of the cellular and scrapie hamster prion proteins," European Journal of Biochemistry, vol. 176, no. 1, pp. 21-30, 1988.

[28] B. W. Caughey, A. Dong, K. S. Bhat, D. Ernst, S. F. Hayes, and W. S. Caughey, "Secondary structure analysis of the scrapie-associated protein $\operatorname{PrP} 27-30$ in water by infrared spectroscopy," Biochemistry, vol. 30, no. 31, pp. 7672-7680, 1991.

[29] A. Taraboulos, A. J. Raeber, D. R. Borchelt, D. Serban, and S. B. Prusiner, "Synthesis and trafficking of prion proteins in cultured cells," Molecular Biology of the Cell, vol. 3, no. 8, pp. 851-863, 1992.

[30] S. B. Prusiner, M. P. McKinley, K. A. Bowman et al., "A protease-resistant protein is a structural component of the scrapie prion," Cell, vol. 35, no. 1, pp. 57-62, 1983.

[31] M. Fischer, T. Rulicke, A. Raeber et al., "Prion protein (PrP) with amino-proximal deletions restoring susceptibility of $\operatorname{PrP}$ knockout mice to scrapie," EMBO Journal, vol. 15, no. 6, pp. 1255-1264, 1996.

[32] P. Sengupta, K. Garai, B. Sahoo, Y. Shi, D. J. Callaway, and S. Maiti, "The amyloid $\beta$ peptide $(\mathrm{A} \beta 1-40)$ is thermodynamically soluble at physiological concentrations," Biochemistry, vol. 42, no. 35, pp. 10506-10513, 2003.

[33] R. Sinigaglia-Coimbra, E. A. Cavalheiro, and C. G. Coimbra, "Postischemic hyperthermia induces Alzheimer-like pathology in the rat brain," Acta Neuropathologica, vol. 103, no. 5, pp. 444-452, 2002.

[34] H. L. Chu and S. Y. Lin, "Temperature-induced conformational changes in amyloid $\beta(1-40)$ peptide investigated by simultaneous FT-IR microspectroscopy with thermal system," Biophysical Chemistry, vol. 89, no. 2-3, pp. 173-180, 2001.

[35] S.-Y. Lin, H.-L. Chu, and Y.-S. Wei, "Secondary conformations and temperature effect on structural transformation of amyloid $\beta$ (1-28), (1-40) and (1-42) peptides," Journal of Biomolecular Structure and Dynamics, vol. 20, no. 4, pp. 595601, 2003.

[36] P. Faller and C. Hureau, "Bioinorganic chemistry of copper and zinc ions coordinated to amyloid- $\beta$ peptide," Dalton Transactions, vol. 21, no. 7, pp. 1080-1094, 2009.

[37] D. Drago, S. Bolognin, and P. Zatta, "Role of metal ions in the $\mathrm{A} \beta$ oligomerization in Alzheimer's disease and in other neurological disorders," Current Alzheimer Research, vol. 5, no. 6, pp. 500-507, 2008.

[38] E. Gaggelli, H. Kozlowski, D. Valensin, and G. Valensin, "Copper homeostasis and neurodegenerative disorders (Alzheimer's, prion, and Parkinson's diseases and amyotrophic lateral sclerosis)," Chemical Reviews, vol. 106, no. 6, pp. 19952044, 2006.

[39] P. W. Mantyh, J. R. Ghilardi, S. Rogers et al., "Aluminum, iron, and zinc ions promote aggregation of physiological concentrations of $\beta$-amyloid peptide," Journal of Neurochemistry, vol. 61, no. 3, pp. 1171-1174, 1993.

[40] C. S. Atwood, R. D. Moir, X. Huang et al., "Dramatic aggregation of alzheimer by $\mathrm{Cu}(\mathrm{II})$ is induced by conditions representing physiological acidosis," Journal of Biological Chemistry, vol. 273, no. 21, pp. 12817-12826, 1998.

[41] E. House, J. Collingwood, A. Khan, O. Korchazkina, G. Berthon, and C. Exley, "Aluminium, iron, zinc and copper Influence the in vitro formation of amyloid fibrils of $A \beta 42$ in a manner which may have consequences for metal chelation therapy in Alzheimer's disease," Journal of Alzheimer's Disease, vol. 6, no. 3, pp. 291-301, 2004.

[42] A. I. Bush, W. H. Pettingell, G. Multhaup et al., "Rapid induction of Alzheimer A $\beta$ amyloid formation by zinc," Science, vol. 265, no. 5177, pp. 1464-1467, 1994.

[43] K. H. Lim, Y. K. Kim, and Y. T. Chang, "Investigations of the molecular mechanism of metal-induced $\mathrm{A} \beta$ (1-40) amyloidogenesis," Biochemistry, vol. 46, no. 47, pp. 1352313532, 2007.

[44] E. F. Ali, F. Separovic, C. J. Barrow, S. G. Yao, and K. J. Barnham, "Copper and zinc mediated oligomerisation of A $\beta$ peptides," International Journal of Peptide Research and Therapeutics, vol. 12, no. 2, pp. 153-164, 2006.

[45] A. I. Bush, "The metallobiology of Alzheimer's disease," Trends in Neurosciences, vol. 26, no. 4, pp. 207-214, 2003.

[46] J. Dong, C. S. Atwood, V. E. Anderson et al., "Metal binding and oxidation of amyloid- $\beta$ within isolated senile plaque cores: raman microscopic evidence," Biochemistry, vol. 42, no. 10, pp. 2768-2773, 2003.

[47] T. Miura, K. Suzuki, N. Kohata, and H. Takeuchi, "Metal binding modes of Alzheimer's amyloid $\beta$-peptide in insoluble aggregates and soluble complexes," Biochemistry, vol. 39, no. 23, pp. 7024-7031, 2000.

[48] S. T. Liu, G. Howlett, and C. J. Barrow, "Histidine-13 is a crucial residue in the zinc ion-induced aggregation of the $\mathrm{A} \beta$ peptide of Alzheimer's disease," Biochemistry, vol. 38, no. 29, pp. 9373-9378, 1999.

[49] N. Arispe, J. C. Diaz, and M. Flora, "Efficiency of histidineassociating compounds for blocking the Alzheimer's $\mathrm{A} \beta$ channel activity and cytotoxicity," Biophysical Journal, vol. 95, no. 10, pp. 4879-4889, 2008.

[50] D. Valensin, P. Anzini, E. Gaggelli et al., "Fac-Ru(Co $)_{3}{ }^{2+}$ selectively targets the histidine residues of the $\beta$-amyloid peptide $1-$ 28. Implications for new Alzheimer's disease treatments based on ruthenium complexes," Inorganic Chemistry, vol. 49, no. 11, pp. 4720-4722, 2010.

[51] Y. Miller, B. Ma, and R. Nussinov, "Zinc ions promote alzheimer a $\beta$ aggregation via population shift of polymorphic states," Proceedings of the National Academy of Sciences of the United States of America, vol. 107, no. 21, pp. 9490-9495, 2010.

[52] V. B. Gupta, S. Anitha, M. L. Hegde et al., "Aluminium in Alzheimer's disease: are we still at a crossroad?" Cellular and Molecular Life Sciences, vol. 62, no. 2, pp. 143-158, 2005.

[53] P. Zatta, M. Favarato, and M. Nicolini, "Deposition of aluminium in brain tissues of rats exposed to inhalational of 
aluminium acetylacetonate," NeuroReport, vol. 4, no. 9, pp. 1119-1122, 1993.

[54] F. Ricchelli, D. Drago, B. Filippi, G. Tognon, and P. Zatta, "Aluminum-triggered structural modifications and aggregation of $\beta$-amyloids," Cellular and Molecular Life Sciences, vol. 62, no. 15, pp. 1724-1733, 2005. 

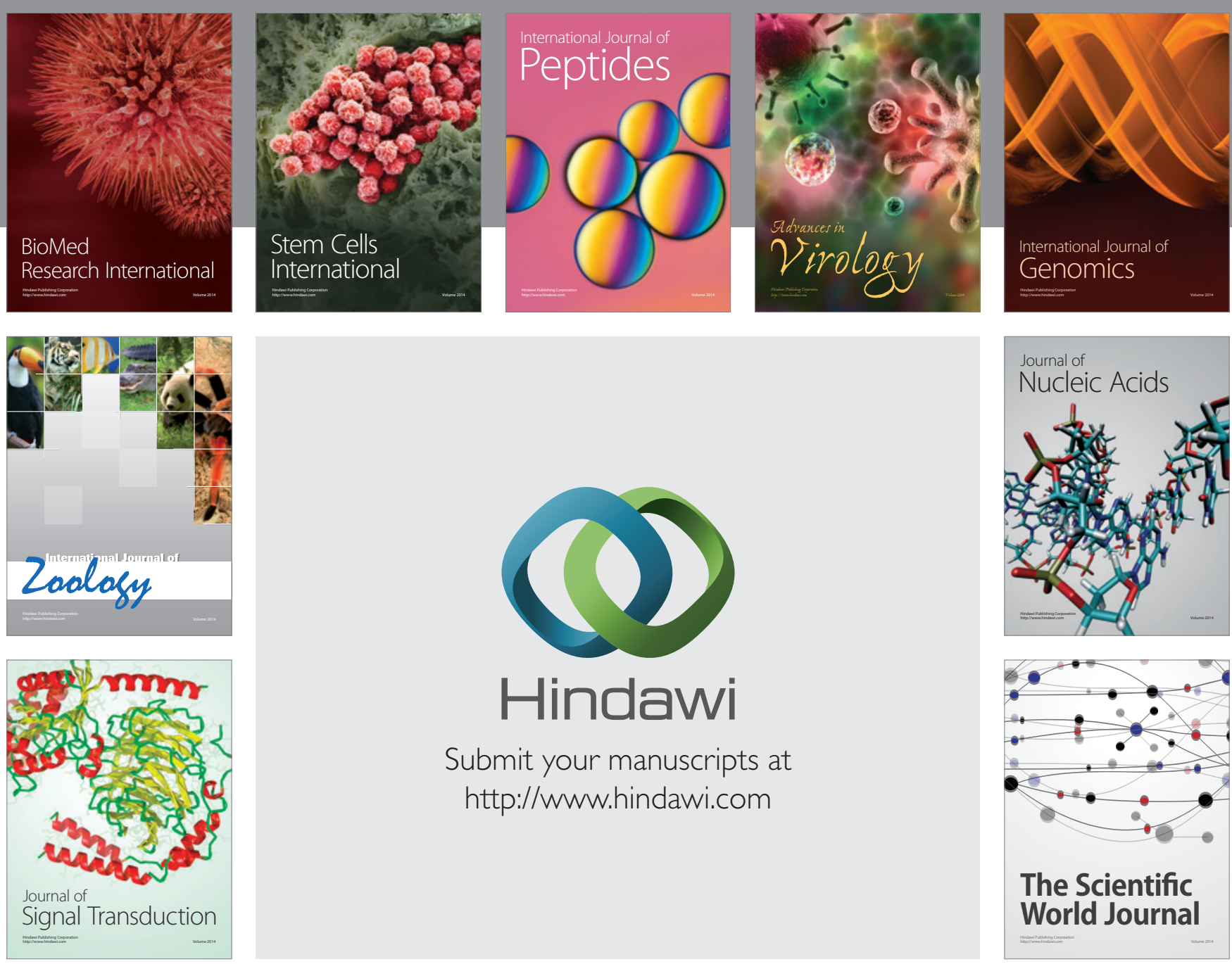

Submit your manuscripts at

http://www.hindawi.com
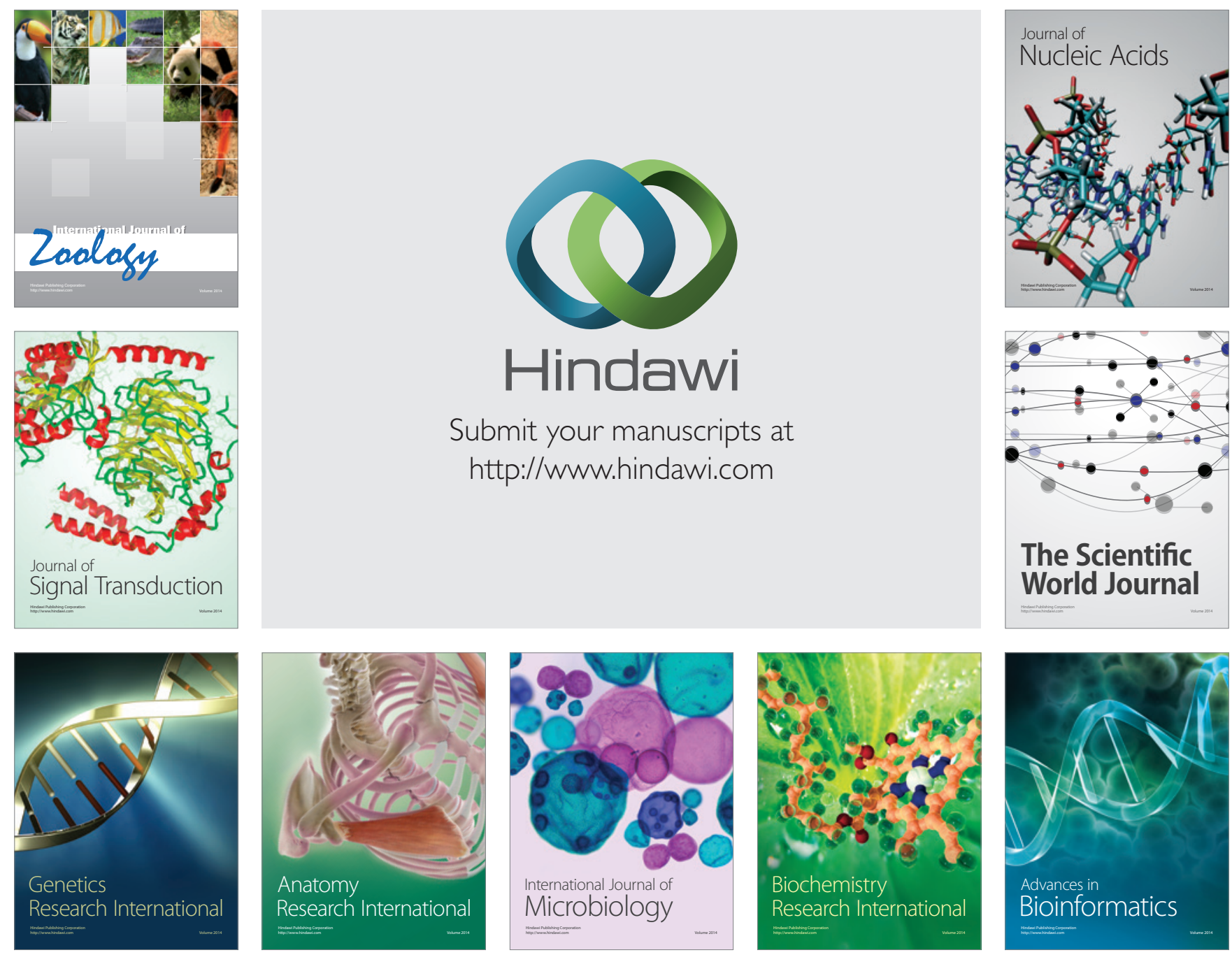

The Scientific World Journal
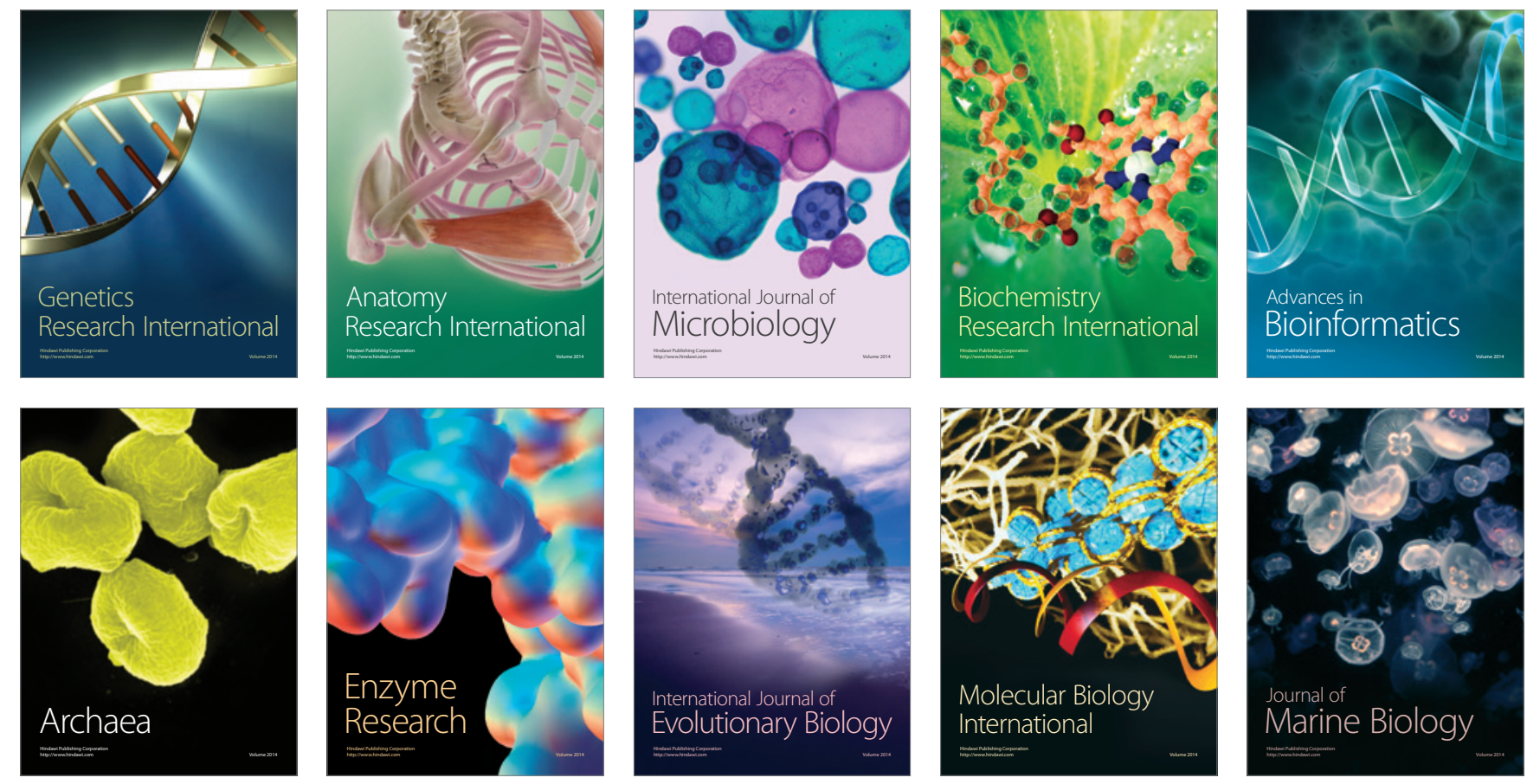